\title{
Place-Making, Provisional Return, and Well-Being: Iraqi Refugee Women in Australia
}

\author{
Katie VASEY
}

\begin{abstract}
Returning to Iraq, even for a visit, was something Iraqi refugees residing in Australia could only dream about while Saddam Hussein remained in power because the ongoing social, economic, and political conditions made return impossible. Despite danger and chaos, the fall of Saddam Hussein's regime (May-December 2003) gave exiled Iraqis the unique opportunity to visit their homelands. In this article, I draw on ethnographic research conducted with 26 Iraqi Shi'i women from refugee backgrounds who resettled in a small country town in Australia. I explored their experiences of provisional return to Iraq, and questioned how their return influences their "home" making in Australia. In this context, I interrogated the complex, contradictory and ambivalent relationships that Iraqi women developed with both their host and home countries and how this impacted upon their well-being.
\end{abstract}

\section{Résumé}

Les réfugiés irakiens installés en Australie ne pouvaient que rêver d'un retour en Irak, même pour une visite, tant que le régime de Saddam Hussein restait en place puisque la situation sociale, économique et politique rendait ce retour impossible. Malgré les dangers et le chaos inhérents au changement, la chute du régime de Saddam Hussein (mai-décembre 2003) a donné aux exilés irakiens l'opportunité unique de visiter leur pays d'origine. Cet article repose sur une étude ethnographique effectuée par l'auteur auprès de 26 irakiennes Shi'i réfugiées qui se sont installées dans une petite ville de l'arrière-pays australien. On y explore leur expérience d'un retour temporaire en Irak, et comment ce retour a influencé leur création d'un "chezsoi» en Australie. Dans ce contexte, l'auteur a examiné les relations complexes, contradictoires et ambivalentes qu'entretenaient ces femmes irakiennes avec leur pays d'adoption et leur pays d'origine, et comment elles ont affecté leur bien-être.

\section{Introduction}

What are we doing here? Balancing between two boats. We drag our souls over days and seasons, while our traditions, our roots, keep getting diluted. Watered down by filtered, distilled circumstances. We [might] never go back. We are grateful and live meaningful lives here, but why this longing; why does this sense of non-belonging niggle us? Why do we catch this 'transplantation torment' like a virus every now and again? This eternal question plays hopscotch with our minds. What price do we pay for clean roads, health care, safety, and shiny cars. What pound of flesh do we bargain for, for a foreign passport. Where do we really live?

As suggested in the above excerpt from an interview conducted with Fatima, ${ }^{1}$ while she yearns for her country of origin, she does not necessarily want to return there. Life is safe and meaningful in Australia, yet the persistent longing for somewhere or something else comes across clearly in her words. In recent decades, migration across and within borders has both intensified and diversified, with vast numbers of people afflicted by displacement, dislocated from national, regional, and ethnic locations. This has raised significant questions concerning mobility, deterritorialized identities, and diasporic forms of belonging across nation-state boundaries. ${ }^{2}$ In fact, uprootedness from the soil of home and place has resulted in a general condition 
of "homelessness," referred to as the diasporic condition. ${ }^{3}$ The search for a "home" forms the basis for this paper: does home move where the migrant moves; is it forever tied to place, soil, and kinship; or does home lie somewhere in between?

Although many refugees and migrants who cannot return to their country of origin aspire to resettle permanently in a new country, this is a rare opportunity. Threequarters of the world's refugees reside in countries neighbouring their country of origin, often living illegally in temporary camps. ${ }^{4}$ In 2010, 108,000 out of 10.55 million of the world's Convention refugees were offered resettlement in one of 22 countries participating in UNHCR's resettlement program. ${ }^{5}$ Australia offers places to approximately 13,000 refugees annually as part of its program of migration. ${ }^{6}$ For the majority, resettlement is part of the process of placement in a third country. Resettlement may be traumatic, in part because the host country, the timing, and the conditions of resettlement are not always freely chosen. The arbitrary decision making, the sometimes haphazard direction of people to new settings and the disregard of prior relationships and networks have created a diasporic scattering of families and communities across the globe. ${ }^{7}$ Yet relatively little attention has been given to the convergent and ongoing process of forced emplacement ${ }^{8}$ and the establishment of connections to place among people from refugee backgrounds in these contexts. ${ }^{9}$ The focus on displacement has left a gap in our understanding of emplacement and of the connections to place in settlement settings that allow refugees and other humanitarian migrants to recreate a sense of home and relative safety. ${ }^{10}$ A relatively small cohort of Iraqi refugees and humanitarian settlers have resettled in Australia, where they are expected to build (from virtually nothing) a new life, and to create "home," literally and metaphorically, in a new place. ${ }^{11}$ For Iraqi immigrants, as the above extract illustrates, moving to and building a "home" in Australia can mean that contradictory emotions perme ate their experiences of resettlement. Each place represents different elements of what constitutes home, impacting upon and underscoring women's understanding of belonging and longing.

Through the prism of imagined and provisional return to Iraq after the fall of Saddam Hussein and his regime (MayDecember 2003), in this article I explore how Iraqi women from refugee backgrounds articulate dimensions of home and its associated longing and belonging in exile, highlight the dynamic nature of these emotional negotiations, and illustrate the interconnectedness of place. By exploring how people are simultaneously both "here and there," I offer an explanation for the varying and complex expressions that provisional return may take, as the women with whom I worked showed that it is misleading to draw clear boundaries between the past and the present, here and there, or to juxtapose these terms with Australia on the one side and Iraq on the other when one is considering the location of home. In order to explore how women's experiences of provisional return to Iraq influence their "home" making in Australia, a brief discussion of the conceptualization of the meaning of "home" embraced by refugees and migrants is necessary.

\section{Refugees, Home, and Place}

The search for "home" and how people set about making themselves "at home" necessitates discussing the dispersed nature of "home." "Home" is a significant analytic category to understand changing constructions of place, for it is central in understanding shifting notions of belonging to place. ${ }^{12}$ Over the past two decades there has been a shift away from essentialist or naturalized assumptions about the people and place relationship. ${ }^{13}$ Whereas "home" may once have been considered fixed, unchanging, and stable in terms of geography, governance, and institutions, such a linear focus fails to acknowledge the changing personal, historical, social, and political contexts through which "home" is continually redefined. ${ }^{14}$ It also fails to address how people's relationships to particular places are continually changing, being made and remade over time and space. ${ }^{15}$ This does not mean that concepts of home are less important or that people are less attached to place, but that its dimensions are more multifaceted; ${ }^{16}$ particularly accompanying forced migration, ongoing war and violence in the country of origin. While the meaning of "home" is not culturally universal and not always tied to a single place, the disruptions of war may require new and more pragmatic considerations. A broader and more mobile concept of home is necessary, something to be taken along as individuals move through space and time. ${ }^{17}$ In this sense home can be transformed, newly invented, and developed in relation to the circumstances in which people find themselves or choose to place themselves. ${ }^{18}$ Belonging to a place, a home, or a people becomes an experience of being within and in between sets of social relations. ${ }^{19}$ The relationship between people who become refugees and place is positioned somewhere in between, and includes a strong sense of connection to places left behind and their associated traumas while at the same time acknowledging the possibilities of (re) building connections to place within the context of resettlement, ${ }^{20}$ as involuntary displacement marks a very real loss of human capital that is not easily re-established. ${ }^{21}$ The complex spatial strategies that refugees develop for negotiating places in which they are physically present, while concurrently negotiating ongoing social, economic, and emotional 
relationships with places from which they are physically absent, has been described as reterritorialization. ${ }^{22}$ These strategies have been explored in several ways in the resettlement context, most notably concerning place-attachment ${ }^{23}$ including the role of religion in overcoming alienation in places of resettlement, ${ }^{24}$ the ways in which the gendering of place relates to feelings at home, ${ }^{25}$ and how places can be therapeutic landscapes. ${ }^{26}$ What forces would lead immigrants from Iraq to uproot themselves and abandon the soil of home to migrate to Australia?

\section{Iraqis on the Move: Coming to Australia}

The oppressive policies of the regime of Saddam Hussein, the Iran-Iraq war (1980-1988), the Gulf crisis starting with the invasion of Kuwait in 1990, the subsequent Gulf War in 1991 and the Intifada, economic hardship during the sanction years (1991-2003), the more recent Gulf War (April-May 2003), and subsequent ongoing domestic and international conflict have all contributed to internal displacement and refugee flows to neighbouring countries and around the world.

Iraqi people do not have a long history of migration to Australia, and have come mainly from countries of first asylum neighbouring Iraq. The Iraqi population is one of the smallest but fastest-growing groups in Australia. ${ }^{27}$ Only 288 Iraqi people had arrived in Australia before 1981. By 1986 , the population had risen to 4,516 . By the end of the Gulf War in 1991, the size of the Iraqi-born community in Australia was 5,186 . The population increased by 77.3 percent (10,827 persons) between 1996 and 2001. Since 1996, over 10,000 Iraqi people have settled in Australia, the majority (77 percent) having arrived through the Refugee and Humanitarian Programs for permanent resettlement, with the remaining 23 percent entering either through the family or skilled stream or as undocumented asylum seekers. ${ }^{28}$ Since then, Australia has accepted increasing numbers of Iraqi refugees and asylum seekers fleeing gross violations of human rights, violence, civil war, socio-economic disasters, life-threatening circumstances, and destitution, under the rule of Saddam Hussein of the Ba'athist Party and following the 2003 invasion. ${ }^{29}$ From 2000 until 2010, Iraqi refugees were among the top four nationalities accepted under the Humanitarian Program. ${ }^{30}$

Australia has a history of changing refugee and migration policies, in terms of criteria to migrate and acceptance, and in relation to resettlement strategies-from the White Australia policy to assimilation and multiculturalism. These all have their own discourse and have impacted on the lives of refugees entering Australia in different ways. The policy in place when refugees enter Australia can have a profound influence on their settlement experience. For example, between 1999 and 2008, a clear distinction in policy was established between refugees holding temporary protection visas (TPVs) and those issued permanent protection in Australia. TPV refugees are mostly excluded or restricted from government-funded welfare services, language tuition, university places, and family reunion programs, whereas permanent humanitarian visa entrants are entitled to the full range of services provided by the Australian government. ${ }^{31}$

In addition to restrictive immigration legislation and policies, the resettlement of large numbers of Iraqi immigrants to Australia occurred during a period when attitudes to refugees were skewed by persistent popular anti-Islamic and anti-Arab sentiment, inflamed by the convergence of international and local factors including the September 11, 2001, attack on the World Trade Center in New York City, the 2002 bomb blast in Bali, and Australian military involvement in Iraq and Afghanistan. These highly publicized events were fuelled further in Australia by debates in political arenas and the media, whereby the "Arab other" was regarded with suspicion, and people from Middle Eastern backgrounds were (and still are) treated as foreigners, even though many have formal citizenship status, or through other official documentation mechanisms, similar privileges and rights of formal citizenship. The change in government in Australia in November 2007 led to some immediate changes in policy, programs, and perceptions of immigrants, but even so, the general uneasiness regarding settlers from Iraq and elsewhere in West Asia pertains.

\section{Methods and Study Participants}

The case material presented below derives from ethnographic research conducted between 2003 and 2007 with Iraqi women from refugee backgrounds in a regional town in Victoria, Australia, referred to pseudonymously as Taraville, where, for the last 15 years, there has been a steady flow of Iraqi settlers. The key research methods included group discussions and participant observation; in-depth interviews conducted over a period of 15 months with 26 Iraqi women, 16 service providers, and members of the wider community; and archival research and analysis of national media. These tools are part of the methodology of ethnographic research ${ }^{32}$ which can provide insights into the meanings of transition and resettlement ${ }^{33}$ and give voice to refugee experiences. $^{34}$

The Iraqi settlers had all entered Australia under the Refugee and Humanitarian Program. Although they had common humanitarian roots and were all practicing Shi'i Muslims mainly from the south of Iraq, their backgrounds were diverse. Their life circumstances in Australia also varied. A number had an extensive network of family members 
both locally and elsewhere in Australia, whereas others had no extended family in Australia, with all their surviving relatives in Iraq or spread across multiple countries. The ages of the participants ranged from 21 to 42 years. All participants were married and their family sizes ranged from no children to seven children. Some people spoke fluent English while others spoke only a few words. The vast majority were welfare dependent, although several were employed, working either on a permanent basis or seasonally in the agricultural industry.

Sixteen service providers were also interviewed, all of whom were involved with migrants and migration projects in different capacities; they included local and regional civil servants, councillors, a multicultural project worker, a trauma and torture counsellor, maternal and child health nurses, primary school and secondary school teachers, ESL teachers, community development workers, human resource managers, and volunteers at the Community House. Several key informants, not directly involved with the Iraqi community, were also interviewed. They included horticultural employers, church members, a member of the historical society, a journalist, several people who had spent their whole lives in Taraville, an Iraqi academic, and Turkish and Italian migrants also residing in Taraville.

Contextual data derive from participant observation: I attended a diverse array of women-only activities, including religious celebrations, day trips, and gatherings in homes. In addition to informal time spent with women in their homes and other social settings, I worked as a volunteer in English as a Second Language (ESL) classes and provided home tutoring. I also participated in resettlement related projects for Iraqi women and attended initiatives organized by different community development agencies. I also attended home visits with the Arabic Family Support Officer and with the maternal and child health nurses, observed mothers' and children's groups at the crèche, and attended meetings including DIMIA (Department of Immigration and Multicultural and Immigration Affairs; now DIAC or Department of Immigration and Citizenship), and with regional and local service provider meetings.

The core of this paper derives from data collected from in-depth interviews with 26 Iraqi women, conducted in English and Arabic, the latter with interpretation by my research assistant, Safria (a pseudonym). ${ }^{35}$ In particular, I focus upon interviews of women who returned temporarily to Iraq after the fall of Saddam Hussein and his regime (May-December 2003). Almost half of my study participants made a trip to their homelands during 2004, some with the intention of testing the water for permanent repatriation, others for a visit only. Several women spoke with me, or with Safria and me, on two or more occasions.
All interviews were conducted in women's homes, and ranged from one to six hours, depending on how much women wanted to share. The interviews were unstructured and open-ended, allowing the women to direct the course of the conversations, so enabling new issues to come to light, particularly regarding the rapidly changing circumstances in Iraq.

\section{Findings}

Iraqi Women and Imagined Return

A study exploring Iraqi refugees in London found that the "history of the communities, the circumstances of their flight and their relationship with the people and the land they have left behind" 36 all shape the perceptions of being a refugee. Among Iraqi Arabs, a refugee is someone who "cannot go back home," whereas Assyrians regard a refugee as "one who does not have a home." Accordingly, these statements are rooted in the "history of the two communities, the circumstances of their flight and their relationship with the people and the land they have left behind." 37 Many of the personal stories of dispersal from the women in this study were tragic both in terms of the conditions that forced them to flee and in terms of the circumstances of flight and the living conditions in countries of asylum before being granted refugee status in Australia. They described becoming refugees as a result of suffering under Saddam Hussein's regime of death, persecution, fear, and domestic exile, of human rights violations, of the crumbling and disintegration of their social worlds. In the majority of cases this was due to their ethnic and religious affiliation as Shi' is or due to their affiliation, either as wives or relatives of male political activists or war deserters. As a result women in this study perceived their refugee status as resulting from the fact that they "cannot go back home," suggesting their orientation and relationship with Iraq-they would like to return but they cannot. Reim ${ }^{38}$ explained longing for the homeland within the context of the historical trauma of war, rupture, and exile:

The home is very dear-do you understand me? Like, it is very important. No one wants to leave his or her country because the country is very dear, but we were obligated to leave our country because of the bad regime, because of the wars, because we suffered too much. So we left Iraq, but it was very hard to leave our country, but we were obligated to leave Iraq. Until now there is no settling in Iraq, no going back to Iraq.

Prior to 2003, many women retained the view, despite the political regime in Iraq, the trauma of war, rupture, and displacement, that their exile was temporary and that they would eventually return. ${ }^{39}$ In an interview, I asked Zara ${ }^{40}$ 
if she imagined returning to Iraq. She replied, "I didn't imagine that I would stay away from Iraq for 9 or 10 years. I thought maybe I would be away for 1 or 2 years and then I would go back to Iraq. I always thought that I would return to Iraq after a short time." She continued, "I will not live here forever. One day I will go back to Iraq. I know that my exile will not last forever. It is a passing moment in my life. I will return to my country." Such statements reflected women's feelings that their time in Australia was indefinite but transitory.

The experience of forced displacement sets in motion processes of identity formation by which the construction of the homelands, coupled with the hope of one day returning to the places left behind, emerges as a fundamental dimension of exilic life. ${ }^{41}$ Return is conceived as an idealized construct whereby people reinvent a past and imagine a fictitious future that would reconnect them with their "home."42 But perceptions of return do not exist only in refugees' minds, whereby they imagine resuming their lives in an idealized place frozen in (mythic) time and space, as though returning to a place, void of socio-political realities. ${ }^{43}$

\section{Iraqi Women, Resettlement in Australia, and Imagined Return}

The idea and possibility of return can be an important aspect of migrants' lives in another country, even if the return never takes place. A critical dimension to understanding imagined and actual return is linked to the process of displacement and resettlement. Understanding these processes requires consideration of the broader social, political, and policy environment of surrounding refugees' settlement experiences. One of the reasons why migrants may wish to return is dependent on how migrants understand their position in host societies. ${ }^{44}$ The yearning for the homeland is rooted not only in the context of displacement but also in the experience of exile. Imagining the homeland and the possibility of return are anchored in and deeply affected by the reality of resettlement. For many Iraqi women resettlement in Australia has been particularly challenging, and many women had to confront multiple barriers while adjusting to a society dramatically different from that with which they were familiar, both as a result of stigmatization related to their religion, language, country, and dress, and because of people whose own style was regarded as challenging and confronting. ${ }^{45}$ Some Iraqi women I spoke with hold on to the idea that they will eventually return to their country of origin, in part because of the social and economic marginalization they experience, but also because of their wish to be reunited with family, to return to a place with which they are familiar and comfortable. Women often spoke of returning permanently to Iraq, emphasizing settlement experiences as key factors propelling them to desire permanent return. Women alluded to the restrictive immigration and refugee policies in Australia, the limited reception and settlement strategies that prevented their full inclusion in Australian society, including minimum or no opportunities for social and economic interaction with nationals. Perceived exclusion on multiple fronts, in the areas of work, education, and lack of family reunion possibilities, figures prominently in women's narratives of potential return. Shatha, ${ }^{46}$ for example, explained:

Here we can't do anything, because we haven't got enough money to start a business. Money is the problem. If I have money, I will go and see my family. Then I would be happy. It is nice here and safe, but I am cut off from my family. Home for me is in Iraq, because of my family, my sister and brother, they are all in Iraq.

While the everyday pressures in Australia are one reason for return, family separation is a pervasive source of emotional distress in Iraqi women's lives. Extended separation from family members is a continuing link to an unbearable past, and refugees' distress about the fate of those who they have left behind is tied to ongoing trauma. ${ }^{47}$ Consequently, women's perceptions of and orientation towards return were inextricably linked to family separation and the limited opportunities for family reunion in Australia. As Shama ${ }^{48}$ described to me when I asked her about coping with life in Australia, away from her family members: "It's much harder than I ever thought. I wasn't prepared for how much I would miss my family. It is very bad because they can't come here."

Running through women's narratives was a strong sense of ambivalence; at the heart of this ambivalence was the separation from family members in Iraq and elsewhere in the world. This emerged as one of the most pervasive aspects of distress in displacement and contributed to a feeling of not belonging. ${ }^{49}$ On the one hand, women described freedom, peace, and being used to the life in Australia, often describing it as "normal." Yet the insecurity of not having family in the same place and missing them, while living in another country which has now become "home," permeates my informants' accounts, creating their ambivalence and unease. As Shama described:

Everything is different here, but I am now used to it. It is normal. But I miss my family; if my family came here, it would be very good. I would feel like it was home if my family were here. 


\section{Returning to Iraq for the First Time}

Iraqi exile has been transformed in the aftermath of the downfall of Saddam Hussein's regime, as thousands of Iraqis were able to go "home" for the first time in decades after the invasion in 2003. Most returned for a short visit only, but many among them were hoping to return for good. ${ }^{50}$ In the initial six months after the downfall of Saddam Hussein's regime, an estimated 50,000 Iraqi refugees, including Australians, chose to return to Iraq. ${ }^{51}$ Women I interviewed mentioned their desire to reconnect to the memory of the place that they had continued to keep alive in their minds; to view, touch, and smell Iraq again in a material sense. Upon their return to Iraq, however, women had to confront the disjuncture between dream and reality. It is worth noting that people's memories were shaped by somewhat romanticized memories and often fragile links and limited news coverage. Far from experiencing their country of origin as less problematic and multifaceted than that of immigration, ${ }^{52}$ "home" proved bewildering and unfamiliar, a foreign country. The Iraq of their imagination was no longer the same. The memories, and their dreams and hopes for a future that served as an anchor in displacement in Australia, altered upon return to Iraq. As Jasmine ${ }^{53}$ suggested, "I have been dreaming about going to Iraq. I thought I would find Iraq better than when I last saw it, but it wasn't." Women were shocked that the Iraq they now observed was, in fact, worse than the Iraq they remembered. Women were saddened because the Iraqi landscape had changed so dramatically. As Sawsan ${ }^{54}$ illustrated when she recalled her first moments in Baghdad:

When I entered the border of my city, I was crying because I was very happy, not because I was sad. Yes, I had a sad feeling because I saw a lot of buildings were demolished by the war, but my friend kept saying to me, take an Iraqi breath, an Iraqi breath and it was a wonderful feeling, you can't imagine. And I was saying to the driver I want to go to my family home and I mentioned the name of the street, and he said "ok, we are very close to that street." I was shivering. When we entered the street, I said "no, this is not the street" and another person in the taxi said "it is the same street" and I said "no the street was much more beautiful."

Other women also noted the impact of the war on cities, towns, and other physical landscapes. For example, as Zahra $^{55}$ described it, Iraq was like a desolate desert that caused her to feel sick: "It is like it is dark in Iraq, when we arrived it was dark. Everything is upside down, it was like a desert, there is no life and no greenery and everything is destroyed. I was shocked and sick when I saw Iraq."

The legacy of the wars, economic destruction, and political upheaval on the Iraqi people was palpable. The return to the "physical site of violence, the political site of repression, and the emotional site of memories," 56 which had precipitated flight many years before, was confronting and challenging. Women were disturbed to find the current economic circumstances, security, infrastructure, and communications all worse than they were under Saddam Hussein, and violence was a primary concern and most profoundly affected their sense of "home" in Iraq. By the time women were able to return to Iraq post-Saddam Hussein, violence, suppression of freedom and of thought, and the violation of property rights had been endemic for decades, producing a "culture of terror and fear." People were also subjected to the coalition forces and Iraqi insurgency. Fear was still omnipresent, the threat of violence in the everyday reality for people in Iraq pervasive. The violence, fear, and mistrust disrupted women's ability to find continuity and meaning, thus making their return volatile and fraught with difficulties. As Zahra explained,

It was very terrible in Iraq. When I walk [I have to] stop [because there is a] problem, when I walk, stop and problem. There were many problems. When I went out of the house I was afraid, often the police would stop us and tell us that a bomb was going to explode and we must take care. I worried all the time. When my husband went out, I worried. Life is too hard in Iraq; people are tired, always nervous, irritable and worried. There is no system in Iraq; it is chaos.

Yet contrarily, women also described a sense of wellbeing when reuniting with family members, and the emotional distress when they could not. Some women were simply happy to have returned to see their family because they had not seen them for 14 years.

\section{Coming Back to Australia}

Despite the troubled and difficult experiences they felt and witnessed, many women were reluctant to leave family members behind again. Their departure was a time of a deep sense of loss, anxiety, and loneliness. Leaving family members behind to return to Australia was sometimes shattering, as Sawsan emphasized:

It was really a very bad time. The night before I left, everybody was crying, and I was crying three days before I left. I realized $a$ person without family is nothing at all. I was saying to them that I wanted to stay with them and come home for good. But they kept saying to me, no it is not settled yet, it is not a good time to decide, you have to go back to your family. It helped me in the beginning to return to my family [in Iraq], but by the end I felt, no, this is really hard for me. 
Although many extended family members advocated that the women return to Australia, women struggled with leaving family members behind. Reim, for example, found it hard to reconcile the fact that two of her children lived in dire circumstances in Iraq, whilst the rest of her family lived in peace and safety in Australia. She felt that she could not enjoy the freedom she has in Australia, knowing her children were suffering:

I told my husband to let me stay with my son and my daughter because I feel that I can't enjoy the situation [in Australia] anymore. But my husband insisted that I came back to my family here. I am always arguing with my husband, asking him why he didn't let me stay with my children in Iraq. Why didn't he let me die with them? Always there is fighting between the people and the US soldiers. My son is not part of the insurgence but I don't feel peace because by accident they might kill him. I worry about my son and what will happen to him.

As Reim suggests, returning to Australia "involved multiple losses," 57 because she had to confront family separation in dangerous and difficult circumstances. Many women's narratives revealed the ongoing struggle to recover continuity and control on return to Australia, as they were consumed with and deeply affected by the suffering they had witnessed, as Zara revealed: "When I was in Iraq, I saw my family in a bad situation and they suffered too much. Now I think about them and feel sad and cry when I remember them. I feel more nervous now."

Shama also found that she was preoccupied with remembering her family upon her return. As she describes, "It took me a long time to forget my family, to be normal again in Australia when I got back. Everyday for three weeks I was thinking about them all the time, it made me upset and nervous."

Despite the anguish resulting from separation from family members upon return, women also reflected upon the harsh reality of Iraq. Stories were circulating about how Iraqi women kissed the ground when they arrived back in Australia, because they were so happy to be away from the violence, chaos, and uncertainty in Iraq. Many women now shared a disillusioned image of Iraq, which they compared to Australia, as Zara describes:

When I was in Iraq, the women can't go out from their homes because they are surrounded and there are soldiers everywhere. Bombings happen everywhere at anytime. It is not safe. There are big differences between Iraq and Australia, big differences. It is the difference between the earth and the sky.
Women acknowledged that Australia is the better place to live in terms of personal safety and peace; as Zahra suggested: "I decided to go back to Australia when I saw Iraq, it is a different life in Iraq." Shama made similar points:

In Australia I feel at peace and I feel safe, but in Iraq I felt like I was arrested, and I felt that from anywhere a bullet could come and kill me. When I got into cars I wondered if they would be bombed, it was terrible. I am alright in Australia, I feel good, it is better than living in Iraq, and I hope to go and live in Iraq but not now.

Many women mentioned that they had told other women, who remained in Australia, not to consider returning, even for a visit, because of the changes that had occurred in Iraq. This realization led to a conceptual shift in their locus of home and their sense of belonging and where this is best situated. The ways in which time and space have changed women's imagining of Iraq is perhaps best summed up by Zahra, whose orientation shifted from Iraq to Australia once she witnessed life in Iraq:

Before I travelled to Iraq, I didn't feel very happy here in Australia. I felt like I was a stranger, but when I came back I was very happy. I don't feel totally at home in Australia, because I don't have any relatives here. I need my mother, father, sisters and brothers, especially when I have babies. But I would like to stay here because the situation in Iraq is not good. I was very happy to come back here. As I said, before I travelled to Iraq, I didn't feel happy here, I felt like I was strange, that I was a stranger, but when I came back I was very happy. I changed my mind and the idea that I had before changed, and I feel less like a stranger now.

As Zahra's statement portrays, perceptions of what the two places symbolize, where one feels one belongs or is best positioned, do not remain static. Whilst not all Iraqi women would subscribe to Zahra's views, mainly because of the hardships they experience in Australia, many would agree with her statement: that Iraq has changed and it is unsafe to consider returning at this point. Some women still expressed a desire to return to Iraq, although the timelines had shifted. For example, Shama said:

When the US army has gone, and everything is good, and Iraq is a good country, I will go back. Maybe in the next 10 years after they have rebuilt Iraq and that will take a long time. It is alright if Iraqi families in Australia visit their families, but if they go there to live again that is hard, I don't like them to go at this time because it is dangerous. 
Other women will return only if Iraq becomes like Australia in terms of safety and peace. Zara explains, "In Australia we feel in peace and we have freedom and we feel like we are equal with the other people, no one hurts us, so we are free here. If Iraq becomes good and safe like Australia, we will go back, we will return."

Migration stories are permeated with explicit and tacit comparisons of the two places. ${ }^{58}$ Unfortunately, however Iraqi women choose to position and reconcile the differences between Iraq and Australia, and which elements of that "bundle of ideas, practices and relationships" 59 they concentrate upon, they are forced to face the reality of making "home" Australia. This involves reconciling to emotional distress connected to family members, family separation and lack of family reunion possibilities. Other women hold on to the concept of return because of family relations and worrying about family members but, if they had no family members in Iraq, they would not consider returning. Other women too were reconciled to the fact that they would not return to Iraq, despite profound sadness connected to their family members and the conditions in which they live their lives. For Iraqi women, living in Australia involves the emotional pain of separation, loss, grief, disappointment, and exclusion, coupled with a sense of safety and freedom. Many women clearly marked the difference between Australia and Iraq as the difference between the earth and the sky. Each place represents different elements of what constitutes home; and in turn, this impacts upon and underscores notions of belonging and longing. It is at this juncture that we can gain a sense of the shifting ways in which longing and belonging to places are constructed and the ways in which they transcend local and national boundaries. Iraqi women's relationships to Iraq and Australia are neither fixed nor straightforward, as their constructions of belonging in relation to places, people, and social spheres shift according to changing contexts through which "home," and where one is best located, are challenged, redefined, and reinforced.

\section{Conclusion}

There has been significant research on migrants' ongoing relationships with their home country ${ }^{60}$ and in relation to migrant return. ${ }^{61}$ However, relatively less research has focused on the ambiguities and tensions that accompany forced migration compounded by ongoing war and violence in the country of origin and the effects on people who return home ${ }^{62}$ to be powerfully reminded of why they left and their own tenuous ties with a place that has lost its footings. Homecomings - the return to the country of origin-are not a unified social process but a multifaceted experience characteristic of diversity, complexity, and ambivalence that challenges boundedness and fixity. Iraqi women expected to experience a feeling of well-being upon return to Iraq, as they stepped back into the "home country," an idealized place that had allowed them to cope with the anxieties of exile. Such feelings of well-being, security, and being "at home" crumbled with the realization that the social environment had irreversibly changed and that returning permanently to Iraq was impossible. This realization was not only based on the fact that the country had, in their absence, been subjected to ongoing destruction and devastation, but also related to the transformations they had undergone in Australia. In other words, possible comforts of being "back home" are challenged by changes in both the country of return and the migrants themselves, which are greatly intensified in conflict-affected countries.

Refugees return but they do not return, they "go back to their country of origin, but they are not the same, nor are the people in the country of origin." 63 As any displaced and dispossessed person can testify, there is no such thing as a genuine, uncomplicated return to one's home. ${ }^{64}$ For the majority of women who made the journey to Iraq, return was a highly complex process, underscored by a feeling of division between "there and here," indicating the tension between Iraqi women's multiple belongings, what has been defined as the "dialectics of belonging and longing."65 Women's ability to reunite with family members did not seem to reconcile fractures, but rather exacerbated anxieties over the future and amplified the difficulties of family separation women experienced. Likewise, returning to their homelands, and more specifically their families, did not have the power to mitigate the sense of rupture women experience in Australia. Some women returning to Iraq reiterated the importance of being close to family members and how, upon return to Australia, they were acutely reminded of this absence and loss. Others, based on notions of personal safety and relative economic security, have become more firmly rooted in Australia, at least for the coming years, despite their marginalized circumstances in Australia and missing family members in Iraq. Some other women feel compelled to return, to be with and share their lives with family members whatever the cost.

Decisions about where to live led to deeper anxieties about where "home" is and where one is supposed to build a future, and what one should prioritize in this decision. The ability to return has added to this dilemma and Iraqi women's accounts of return demonstrate that each return "creates its own logic, contradictions, and possibilities for the future." 66 Research suggests that crossing national boundaries involves a process of re-creation. ${ }^{67}$ It is an imaginative process for migrants, because they travel into realms where what has been left behind and future possibilities are continually reimagined and re-evaluated. In addition, it 
involves the re-evaluation of one's past, present, and future locations. ${ }^{68}$ Consequently, reassessment of which place is best to be is central to Iraqi women's experiences of migration. However, on an emotional level, wherever one decides to be, one has left some part of oneself in the other place.

Women's narratives of longing, belonging, and return illustrate how the relationships between Iraqi people in Iraq and Australia have changed irreversibly, both by separation over space and over time. ${ }^{69}$ Becoming and being a migrant is always embedded in local social and political relations, and made sense of within the social and political frameworks provided by each context. The experiences documented in this article show that it is misleading to draw clear boundaries between the past and the present, here and there, or to juxtapose these terms with Australia on the one side and Iraq on the other. For immigrants, communication continues between there and here, the old and the new, and the past and the present ${ }^{70}$ enabling people to make sense out of the complex relationship between belonging and longing in exile, and the permeable location of home, and the realization that being a refugee might mean not being able to remake aspects of "home" in either place, ${ }^{71}$ rendering them both "out of place" and "in place" in both Australia and Iraq. Such contradictions in emotion and affective ties to place lead to considerable ambivalence towards both Australia and Iraq, as countries, cultures, and collectivities of people, or as has been suggested, the contradictions of the migration process are unresolvable through physical mobility, because the feeling of "home" is ultimately an affective and social construction that transcends place. ${ }^{72}$

\section{Notes}

1. Fatima is a journalist from Pakistan who migrated to Melbourne in 1998. Also see F. Sehbai, "On Foreign Ground," The Age (Melbourne), 2002, 21 March 10.

2. See J. Clifford, "Diasporas," Cultural Anthropology 9, no. 3 (1994): 302-38; R. Cohen, Global Diasporas: An Introduction, $2^{\text {nd }}$ ed. (London: Routledge, 2008); K. Fog-Olwig, "Cultural Sites: Sustaining a Home in a Deterritorialized World," in Sitting Culture: The Shifting Anthropological Subject, ed. K. Fog-Olwig and K. Hastrup (London: Routledge, 1997), 17-39; and D. Turton, "The Meaning of Place in a World of Movement: Lessons from Long Term Field Research in Southern Ethiopia” (RSC Working Paper no. 18, Refugee Studies Centre, Oxford, 2004) for significant contributions to debates concerning mobility, deterritorialized identities, and diasporic forms of belonging.

3. N. Hyndman-Rizik, At My Mother's Table: Migration, (Re) production and Return between Hadchit, North Lebanon and Sydney (Newcastle: Cambridge Scholars Publishing, 2011).
4. UNHCR, Global Trends 2010: 60 Years and Still Counting (Geneva: United Nations High Commissioner for Refugees, 2010).

5. UNHCR, 60 Years and Still Counting; UNHCR, Refugee Resettlement: An International Handbook to Guide Reception and Integration (Geneva: United Nations High Commissioner for Refugees, 2002).

6. DIAC, "Australia's Humanitarian Program: Information Paper" (Canberra: Department of Immigration and Citizenship, 2011).

7. K. Vasey and L. Manderson, "The Social and Cultural Context of Immigration and Stress," in Immigration and Suicide, Stress, Psychiatric Disorders and Suicidal Behavior Among Immigrants and Refugees, ed. L. Sher and A. Vilens (New York: Nova Science Publishers, 2010).

8. Hammond has used the term "emplacement" to refer to how people interact with their environment in order to make it feel like home. This involves the inter-working of place, identity, and practice in such a way as to generate a relationship of belonging between person and place. L. Hammond, This Place Will become Home: Refugee Repatriation to Ethiopia (Ithaca and London: Cornell University Press, 2004).

9. D. Turton, "The Meaning of Place in a World of Movement"; and R. Sampson and S. Gifford, "Place-Making, Settlement and Well-Being: The Therapeutic Landscapes of Recently Arrived Youth with Refugee Backgrounds," Health and Place 16 (2010): 116-31.

10. Sampson and Gifford, "Place-Making, Settlement and Well-Being."

11. L. Manderson and S. Rapala, "Making Sense of Disruptions: Strategies of Regrounding of Ailing Polish Immigrants in Melbourne, Australia," Human Organization 64, no. 5 (2005): 350-59.

12. N. Rapport and A. Dawson, Migrants of Identity: Perceptions of Home in a World of Movement (Oxford: Berg, 1998).

13. Sampson and Gifford, "Place-Making, Settlement and Well-Being";

14. K. Gardner and F. Osella, Migration, Modernity, and Social Transformation in South Asia: An Introduction (New Delhi and Thousand Oaks, California: Sage, 2004).

15. Ibid.

16. K. Gardner, Age, Narrative and Migration: The Life Course and Life Histories of Bengali Elders in London (London: Berg, 2002).

17. L. Baldassar, Visits Home: Migration Experiences between Italy and Australia (Melbourne: Melbourne University Press, 2001).

18. Gardner and Osella, Migration, Modernity, and Social Transformation in South Asia.

19. E. Probyn, Outside Belongings (New York and London: Routledge, 1996).

20. Sampson and Gifford, "Place-Making, Settlement and Well-Being." 
21. G. Kibreab, "Revisiting the Debate of People, Place, Identity and Displacement," Journal of Refugee Studies 12, no. 4 (1999): 384-410.

22. C. Brun, "Reterritorializing the Relationship between People and Place in Refugee Studies," Geografiska Annaler 83B (2001): 15-25.

23. C. Bogac, "Place Attachment in a Foreign Settlement," Journal of Environmental Psychology 29 (2009): 267-78.

24. C. McMichael, "Everywhere Is Allah's Place': Islam and the Everyday Life of Somali Women in Melbourne, Australia,' Journal of Refugee Studies 15 (2002): 171-88; and M/ Shoeb, H. M. Weinstein, and J. Halpern, "Living in Religious Time and Space: Iraqi Refugees in Dearborn, Michigan," Journal of Refugee Studies 20 (2007): 441-60.

25. I. Dyck and P. Dossa, "Place, Health and Home: Gender and Migration in the Constitution of Healthy Space," Health and Place 13 (2007): 691-701.

26. Sampson and Gifford, "Place-Making, Settlement and Well-Being."

27. VOMA, "Victorian Community Profiles 2001 Census," (Melbourne: Victorian Office of Multicultural Affairs, 2003).

28. J. Taylor and D. Stanovic, Refugee and Regional Settlement: Balancing Priorities (Melbourne: Brotherhood of St Laurence, 2005).

29. V. Johnston, K. Vasey, and M. Markovic, "Social Policies and Refugee Resettlement: Iraqis in Australia," Journal of Critical Social Policy 29, no. 2 (2009): 191-215.

30. DIAC, "Australia's Humanitarian Program: Information Paper" (Canberra: Department of Immigration and Citizenship, 2011).

31. Johnston, Vasey, and Markovic, "Social Policies and Refugee Resettlement."

32. For ethnographic studies of migrant and refugee return migration, see J. Carling, E. B. Mortensen, and J. Wu, "A Systematic Bibliography on Return Migration" (PRIO Paper, Peace Research Institute, Oslo, 2011).

33. F. L. Ahearn, ed., Psychosocial Wellness of Refugees: Issues in Qualitative and Quantitative Research (Oxford: Berghahn Books, 2000).

34. J. Powles, "Life History and Personal Narrative: Theoretical and Methodological Issues Relevant to Research and Evaluation in Refugee Context," (Working Paper no. 106, New Issues in Refugee Research, UNHCR, Geneva, 2004).

35. Safria left Baghdad after the Intifada in 1991 and spent several years in Iran before coming to Australia as a "woman at risk" refugee in 1997, where she remarried. At the time of the research she lived in public housing with her husband. Her two grown children lived close by. All her family members have left Iraq and now live in surrounding Middle Eastern countries, Europe, and the US.

36. M. Al-Rasheed, "The Myth of Return: Iraqi Arab and Assyrian Refugees in London," Journal of Refugee Studies 7, no. 2/3 (1994): 199-219, 204.

37. Al-Rasheed, "The Myth of Return."
38. Reim fled Iraq following the Intifada in 1991 and spent 12 years in Iran before moving to Australia in 2003. At the time of the research she lived in public housing with her husband and five of her children; two children were left behind in Iraq as they were not granted refugee status. Reim returned to Iraq by herself to see her children after fall of Saddam Hussein.

39. R. Zetter, "Reconceptualising the Myth of Return: Continuity and Transition amongst the Greek-Cypriot Refugees of 1974," Journal of Refugee Studies 12, no. 1 (1999): 1-22.

40. Zara originally came from Najef but left Iraq following the Intifada in 1991 and spent six years in Lebanon. She came to Australia in July 1998, and at the time of the interview she lived in public housing with her husband and three children, who were under eight years old. Her whole family returned to Iraq for a visit after the fall of Saddam Hussein.

41. A. H. Stefansson, Refugee Returns to Sarajevo and Their Challenge to Contemporary Narratives of Mobility (Philadelphia: University of Philadelphia Press, 2004).

42. McMichael, "Everywhere Is Allah's Place'; and M. Israel, "South African War Resisters and the Ideologies of Return from Exile," Journal of Refugee Studies 13, no. 1 (2002): 26-42.

43. J. Newman, "Narrating Displacement: Oral Histories of Sri Lankan Women," (Working Paper No. 29, Refugee Studies Centre, University of Oxford, 2003).

44. Israel, "South African War Resisters and the Ideologies of Return from Exile."

45. See P. Dossa, Politics and Poetics of Migration Narratives of Iranian Women from the Diaspora (Toronto: Canadian Scholars' Press, 2004); and L. A. McSpadden, Contemplating Repatriation to Eritrea (Philadelphia: University of Philadelphia Press, 2004).

46. Shatha left Basra in Iraq in 1997 and spent several years in Lebanon before coming to Australia as a refugee in 1999. At the time of the research, she was living in public housing with her husband and four children, all under seven years of age. All her relatives remained in Iraq. She returned to Iraq after the fall of Saddam Hussein.

47. See C. McMichael and M. Ahmed, "Family Separation: Somali Women in Melbourne," In Critical Perspectives on Refugee Policy in Australia, ed. M. Leach and F. Mansouri (Geelong: Deakin University, 2003); and A. Williams, "Families in Refugee Camps," Human Organization 42, no. 1 (1995): 100-9.

48. Shama came from Nasiriyya in Iraq and fled in 1991 to Syria, where she spent four years before travelling to Australia as a refugee in 1995. At the time of the research, she lived in public housing with her husband and four children, all under eight years old. She returned to Iraq with her family after the fall of Saddam Hussein.

49. See also McMichael, “Everywhere Is Allah's Place.”

50. N. Al Ali, Iraqi Women: Untold Stories from 1948 to the Present (London and New York: Zed Books, 2007). 
51. D. Romano, "Whose House Is This Anyway? IDP and Refugee Return in Post-Saddam Iraq," Journal of Refugee Studies 18, no. 4 (2005): 432-53.

52. J. Rogge, "Repatriation of Refugees," in When Refugees Go Home: African Experiences, ed. T. Allen and H. Morsink (Trenton: African World Press, 1994).

53. Jasmine came from Baghdad, but left Iraq after the Intifada in 1991 and spent the next nine years in Syria and Lebanon. At the time of the interview she lived with her husband and three children, all under ten years old. Jasmine, her husband, and their children returned to Iraq for a visit after fall of Saddam Hussein.

54. Sawsan left Baghdad in 1990 and spent six years in Iran before coming to Australia as a refugee in 1996. At the time of the interview she lived with her husband and three children, all under eight years old. Sawsan's family remained in Iraq and she returned to Iraq to visit them by herself after the fall of Saddam Hussein.

55. Zahra came from Nasiriyya but left after the Intifada in 1991 along with 17 family members. They spent three years in the Rafha refugee camp in Saudi Arabia, where she married her husband. Zahra came to Australia in 1995. At the time of the research, Zahra lived with her husband and four children, all under the age of ten. Zahra returned to Iraq after the fall of Saddam Hussein with her husband.

56. Newman, "Narrating Displacement," 35.

57. G. Buijs, Migrant Women: Crossing Boundaries and Changing Identities (Oxford: Berg, 1994), 2.

58. M. N. Yelenevskaya and L. Fialkova. "Between Dream Cities and Reality: Personal Narratives of Ex-Soviets in Israel" (presented at 7th Conference of the International Society for Quality-of-Life Studies, Rhodes University, South Africa, 2006).

59. Gardner, Age, Narrative and Migration, 219.

60. See Carling, Mortensen, and Wu, "A Systematic Bibliography on Return Migration."

61. Ibid.

62. See, for example, L. D. Long and E. Oxfeld, eds., Coming Home? Refugees, Migrants and Those Who Stayed Behind (Philadelphia: University of Pennsylvania Press, 2004); A. H. Stefansson and F. Markowitz, eds., Homecomings: Unsettling Paths of Return (Lanham, MD: Lexington Books, 2004); R. Black and S. Gent, Sustainable Return in Postconflict Contexts, International Migration 44, no. 3 (2006): 15-18; J. L. Finlay, R. A. Crutcher, and N. Drummond, "Garang's Seeds: Influences on the Return of Sudanese-Canadian Refugee Physicians to Post-Conflict South Sudan," Journal of Refugee Studies 24, no. 1 (2011): 187-206.
63. D. Warner, "Voluntary Repatriation and the Meaning of Return to Home: A Critique of Liberal Mathematics," Journal of Refugee Studies 7, no. 2/3 (1994): 160-74, 172.

64. E. Said, Out of Place: A Memoir (New York: Knopf, 1999).

65. P. van der Veer, "The Diasporic Imagination," in Nation and Migration. The Politics of Space in the South Asian Diaspora, ed. P. van der Veer (Philadelphia: University of Pennsylvania Press, 1995), 1-17, 4.

66. E. Oxfeld and L. D. Long, "Introduction: An Ethnography of Return, " in Coming Home?: Refugees, Migrants, and Those Who Stayed Behind, ed. L. D. Long and E. Oxfeld. (Philadelphia: University of Pennsylvania Press, 2004), 15.

67. See Gardner, Age, Narrative and Migration; and M. Markovic and L. Manderson, "Crossing National Boundaries: Social Identity among Recent Immigrant Women from the Former Yugoslavia in Australia," Identity: An International Journal of Theory and Research Communication 2, no. 4 (2002): 303-316.

68. See Gardner, Age, Narrative and Migration.

69. Ibid., 217. .

70. M. Chamberlain and S. Leydesdorff, "Transnational Families: Memories and Narratives," Global Networks 4, no. 3 (2004): 227-41.

71. M. Markovic and L. Manderson, "Nowhere Is at Home: Coping Strategies of Recent Immigrants from the Former Yugoslav Republics, Journal of Sociology 36, no. 3 (2000): 315-328.

72. Hyndman-Rizik, At My Mother's Table.

Katie Vasey is a medical anthropologist. She is a research fellow in the School of Psychology and Psychiatry at Monash University in Melbourne, Australia. Her research interests include migration, gender, and health; social and health policy; and Muslim women. She has published widely in these areas. She is currently involved in research exploring the interrelationship between migration, parenthood, and identity with Iraqi women in Australia.

The author would like to acknowledge the University of Melbourne for funding the research and to Lenore Manderson for her comments and suggestions for this article. I also remain indebted to the study participants. 
(C) Katie Vasey, 2011. This open-access work is licensed under a Creative Commons Attribution-NonCommercial 4.0 International License, which permits use, reproduction and distribution in any medium for non-commercial purposes, provided the original author(s) are credited and the original publication in Refuge: Canada's Journal on Refugees is cited. 